\title{
ARTICLE
}

\section{Feeding success and selectivity of larval anchoveta Engraulis ringens in a fjord-type inlet from northern Patagonia (Southeast Pacific)}

\author{
Éxito alimentario y selectividad en larvas de anchoveta Engraulis ringens \\ en un canal tipo fiordo de Patagonia norte (Pacífico Suroriental)
}

\section{Mauricio F. Landaeta ${ }^{1}$, María J. Ochoa-Muñoz ${ }^{1,2}$ and Claudia A. Bustos ${ }^{1}$}

\begin{abstract}
'Laboratorio de Ictioplancton (LABITI), Facultad de Ciencias del Mar y de Recursos Naturales, Universidad de Valparaíso, Avenida Borgoño 16344, Reñaca, Viña de Mar, Chile. mauricio.landaeta@uv.cl

${ }^{2}$ Programa Maestría en Ciencias en Manejo de Recursos Marinos, Centro Interdisciplinario de Ciencias Marinas (CICIMAR), Departamento de Plancton y Ecología Marina, Av. Instituto Politécnico Nacional s/n Col. Playa Palo de Santa Rita, La Paz, Baja California Sur, CP. 23096, México
\end{abstract}

\begin{abstract}
Resumen.- Se investigó la dieta y selectividad de larvas de anchoveta Engraulis ringens durante 4 días consecutivos (primavera) en el canal Hornopirén, un ambiente tipo fiordo del sur de Chile. Este ambiente estuvo caracterizado por una marcada haloclina alrededor de los $10 \mathrm{~m}$ de profundidad, separando aguas salobres y saladas. La oferta potencial de presas, microzooplancton, fue recolectada a 4 profundidades $(0,5,10$ y $30 \mathrm{~m})$, mientras que el ictioplancton fue recolectado en 2 estratos, superficial $(0-10 \mathrm{~m})$ y profundo $(10-45 \mathrm{~m})$. Los nauplii y copepoditos fueron los principales componentes del microzooplancton. El análisis de 487 contenidos estomacales de larvas de anchoveta indicó que se ingirieron volúmenes similares de presa en ambos estratos y durante ambas mareas. Sin embargo, en la capa superficial, salobre y más cálida, las larvas de E. ringens ingirieron significativamente menos presas pero de mayor tamaño, como nauplii y copepoditos como presas principales. En la capa subsuperficial, en aguas más frías y saladas, las larvas ingirieron más presas de menor tamaño, con mayor selectividad por los nauplii. La incidencia alimentaria de E. ringens se incrementó 2 veces durante la marea llenante, cuando la abundancia de los copepoditos también se incrementó. Por lo tanto, es posible detectar interacciones biofísicas complejas en los fiordos Patagónicos durante el proceso de alimentación de los estados larvales de esta especie de importancia comercial, en estrecha relación con la distribución espacio-temporal de las presas.
\end{abstract}

Palabras clave: Dieta, microplancton, Chile austral, mareas, estratificación

Abstract.- The diet and selectivity of larval anchoveta Engraulis ringens was studied during 4 consecutive days (austral spring) in Hornopirén inlet, a fjord-like environment of southern Chile. This environment was characterised by sharp halocline around $10 \mathrm{~m}$ depth, separating brackish and saltier waters. The potential prey field, microzooplankton, was collected at 4 depths $(0,5,10$ and $30 \mathrm{~m})$, while the ichthyoplankton was collected at 2 strata, surface $(0-10 \mathrm{~m}$ depth) and deep (10-45 m depth). Nauplii and copepodites were the major components of microzooplankton. The analysis of 487 gut contents of larval anchoveta indicates that similar volume of prey was ingested in both layers and during both tides. However, in the upper, brackish and warmer water, larval E. ringens ingested significantly less prey but of larger size, selecting nauplii and copepodites as the main prey items. In the deep, saltier and colder water, larvae ingested more prey of smaller size, showing only selectivity for nauplii. The feeding incidence of E. ringens increased twice during the flood, when the abundance of copepodites in the field also increased. Therefore, complex biophysical interactions occur in Patagonian fjords during the feeding process of larval stages of this commercially important species in tight relationship with the spatio-temporal distribution of prey.

Key words: Diet, microplankton, southern Chile, tides, stratification

\section{INTRODUCTION}

Availability of suitable prey in sufficient quantities during the shift from endogenous to exogenous feeding is an important factor determining survival and growth of larval fish (Hinrichsen et al. 2005). The success of fish larvae feeding in the surface layer of the ocean is dependent of complex meteorological, oceanographic, ecological and morphological interactions, and it is species- specific in the requirements and responses to the physical interactions. For example, an increase in turbulence decreases the prey ingestion of larvae of an estuarine 
species (Mahjoub et al. 2012), but increases the feeding and growth performance of an oceanic fish larvae (Kato et al. 2008). In herring, the feeding activity of medium size larvae is mainly related to water transparency, while in large larvae elevated copepod densities increase the feeding activity, and the increase of wind speed and temperature decreases the feeding activity (Arula et al. 2012).

Prey distribution and their characteristics, such as size, pigmentation and motion, also play an important role in the detection of prey for visual foraging by fish (O'Keefe et al. 1998). During the larval stage, most species feed on similar prey (nauplii and early life-history stages of copepods) (Pepin \& Penney 1997, Landaeta et al. 2011). The microzooplankton and other potential prey items for fish larvae aggregates near fronts and clines in highly stratified marine and estuarine areas (Landaeta et al. 2013). Because of this, it is expected that biophysical interactions occur within the pycnocline during the feeding activity (McManus \& Woodson 2012). Then, oceanographic observations must be conducted at spatial and temporal scales relevant to the determination of species composition of distributions to elucidate appropriate driving mechanisms (Woodson \& McManus 2007). A biological model that shows high phenotypic plasticity during early life stages along its latitudinal distribution is the anchoveta, Engraulis ringens (Jenyns, 1842) (Llanos-Rivera \& Castro 2004, 2006; Castro et al. 2009).

Engraulis ringens is subject to an intense $(40,000$ 100,000 ton/year in the last decade, Gutiérrez et al. 2012) and economically important fishery in the south-eastern Pacific from Zorritos, Peru (4³0'S) to Chiloé, Chile (42³0’S) (Claramunt et al. 2012, Gutiérrez et al. 2012). The larval diet is based on phytoplankton, nauplii and copepodites off central Chile (Llanos et al. 1996, LlanosRivera et al. 2004, Yáñez-Rubio et al. 2011), showing a fast-growing strategy $\left(0.40-0.57 \mathrm{~mm} \mathrm{~d}^{-1}\right.$, Hernández \& Castro 2000) but high mortality rates (96-98\% daily, Castro \& Hernández 2000).

This southernmost coastal environment, the northern Patagonian fjords, has different environmental forcing and structure compared with those of upwelling areas from Peru and central Chile. This area is characterised by complex marine-terrestrial-atmospheric interactions that result in high biological production, which increases in austral spring and summer $\left(>1 \mathrm{~g} \mathrm{C} \mathrm{m}^{-2} \mathrm{~d}^{-1}\right.$; Iriarte et al. 2007, González et al. 2010). Freshwater inputs from river run-off, glacial meltwater, and heavy rains loaded with silicic acid currently generate a positive estuarine circulation, with a brackish upper 10-30 m layer of the water column. This layer is separated from a marine water layer loaded with nitrate and orthophosphate by a strong pycnocline, resulting in overlapping limnetic and marine characteristics in the inner seas (González et al. 2010). The complex fjord coastline is sheltered and increases the influence of the semi-diurnal tidal forcing (amplitudes from 1.5 to $8.0 \mathrm{~m}$; Valle-Levinson et al. 2007, Letelier et al. 2011).

For the southern population of E. ringens, larger eggs and spawning and early nursery zones associated to areas with stronger vertical stratification has been recently described (Bustos et al. 2008). However, there is no information about larval feeding strategies or growth in the area. For the southernmost population of E. ringens, can oceanographic conditions affect the diet and selectivity of larvae in a fjord? Our hypothesis is that 2 major oceanographic features of the area, a two-layer water column and the tides, may affect the trophic interactions of fish larvae in a short-term scale of time (from hours to days). The prediction is that the prey field (microzooplankton), the feeding success (expressed as prey composition and size) and selectivity will vary between vertical layers (brackish and marine layers) and between tidal phases (flood and ebb).

\section{MATERIALS AND METHODS}

\section{FiELDWORK}

During 10-13 December 2010 (austral spring) an intensive cruise was carried out in Hornopirén inlet $\left(42^{\circ} 05^{\prime} \mathrm{S}\right.$, $\left.73^{\circ} 35^{\prime} \mathrm{W}\right)$, a fjord-type environment. This area is characterised by the influence of the freshwater inputs of Río Blanco (average annual river discharge: $37 \mathrm{~m}^{3} \mathrm{~s}^{-1}$ ) and Río Cuchildeo $\left(17 \mathrm{~m}^{3} \mathrm{~s}^{-1}\right)$, and it has a maximum depth of $230 \mathrm{~m}$ (Fig. 1). The tidal regime in the area is mainly semidiurnal, with a tidal range between 6 and $7 \mathrm{~m}$ during spring tides and decreases to $1 \mathrm{~m}$ in neap tides (ValleLevinson et al. 2007). The location of the station was selected because it represents a site with the influence of a two-layer water column, with freshwater runoff in surface and saltier water below 30-40 $\mathrm{m}$ depth, and it is influenced by tidal forcing. Also, it has lower density of sea cages of salmon farming than other sectors of the inlet. Each sampling set consisted in a vertical cast of a CTD Seabird SBE-19 from surface to $60 \mathrm{~m}$ depth to characterise the vertical structure of temperature, salinity and density of the water column, sampling of seawater at 4 discrete 


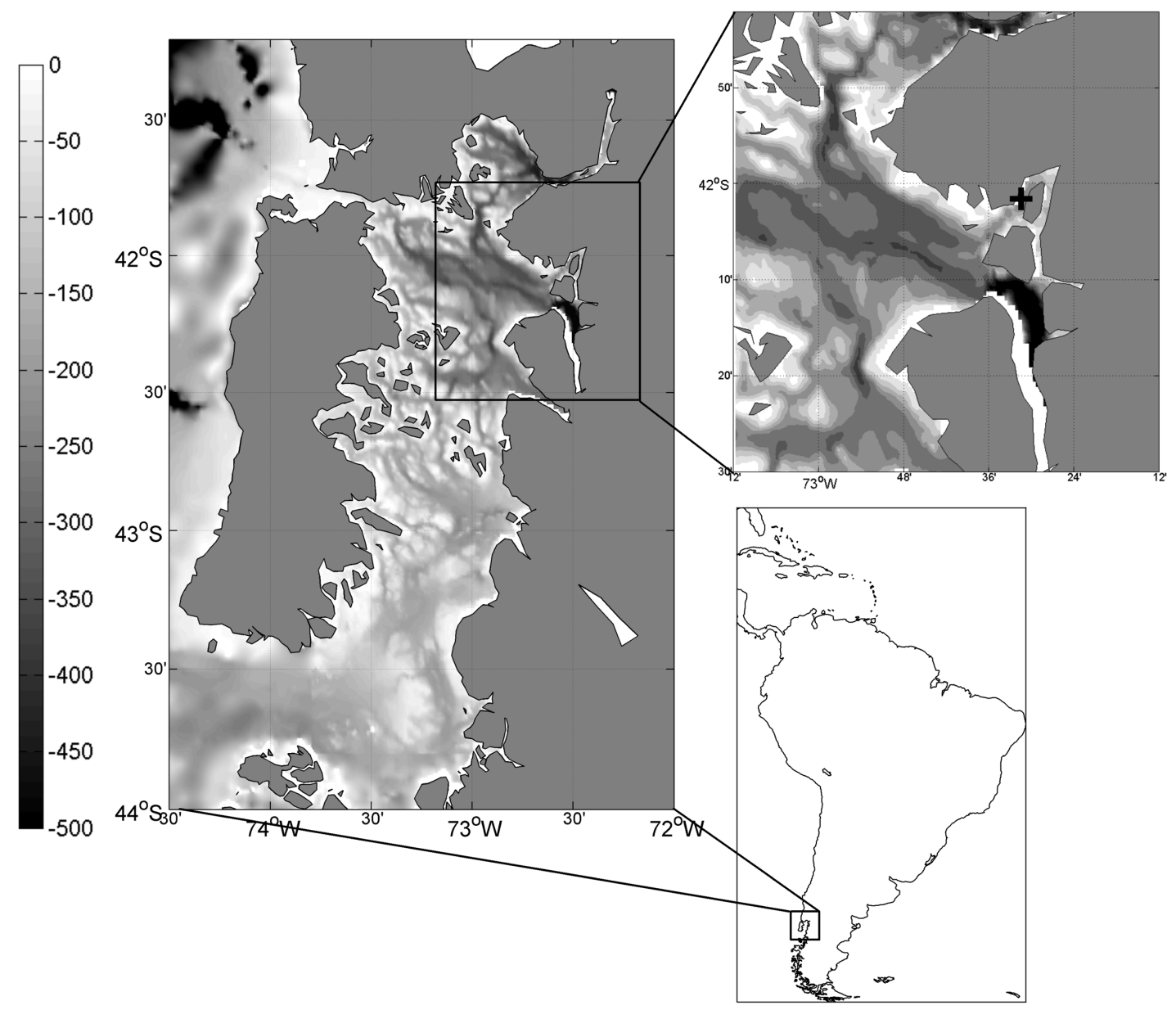

Figure 1. The sampling location of Engraulis ringens larvae during the austral spring cruise in the northern Patagonia of South Pacific Ocean. The cross indicates the station studied in the Hornopirén inlet during four consecutive days of December 2010. The gray scale corresponds to the bathymetry $(m)$ / La ubicación del sitio de muestreo de larvas de Engraulis ringens durante primavera en la Patagonia norte del Océano Pacífico Sur. La cruz indica la estación estudiada en el canal Hornopirén durante 4 días consecutivos de diciembre de 2010. Escala en gris corresponde a batimetría (m)

depths $(0,5,10$ and $30 \mathrm{~m}$ depth) with 5-L Niskin bottles, and 2 oblique trawls with an opening-closing Bongo net (60 $\mathrm{cm}$ diameter, $300 \mu \mathrm{m}$ mesh size, with a TSK flow meter to estimate the filtered seawater) at $0-10 \mathrm{~m}$ (the mixed layer) and 10-45 m depth (pycnocline and deep layer). The seawater collected by Niskin bottles was filtered by a $25 \mu \mathrm{m}$ mesh and the retained material was fixed with 5\% formaline buffered with sodium borate and stored in plastic bottles to identify and estimate microzooplankton abundance, as the potential prey field. Zooplankton captured by Bongo nets was also fixed with $5 \%$ formaline buffered with sodium borate and stored in plastic bottles. Filtered seawater by Bongo net ranged from 15.3 to 303.9 $\mathrm{m}^{3}$ (mean \pm one standard deviation: $84.1 \pm 51.2 \mathrm{~m}^{3}$ ). This sampling set was repeated 20 times, during flooding (10 times) and ebbing conditions (10 times), and mostly during daytime $(75 \%)$, to ensure the presence of food in the guts.

\section{LABORATORY WORK}

In the laboratory, microplankton taken from the Niskin bottles was identified to the lowest possible taxon with an Olympus ${ }^{\circledR}$ SZ5145A dissecting stereomicroscope, and their abundance was standardised at individuals per cubic meter (ind. $\mathrm{m}^{-3}$ ). The zooplankton samples were preserved in $96 \%$ ethanol, and all fish larvae were separated and 
identified to the lowest taxonomic status possible. Larval anchoveta E. ringens were counted and its abundance standardised to individuals (ind.) per $1000 \mathrm{~m}^{3}$. Wellpreserved larvae were measured (body length, BL) under an Olympus ${ }^{\circledR}$ SZ61 stereomicroscope attached with a camera Motic moticam 2500 (resolution 5.0 M Pixel) and the software Motic Image Plus 2.0. The gut of each larva was dissected from the body and opened length-wise with fine needles. Prey items were counted and identified to the lowest possible taxon except for indigestible prey remains, such as setae, under a Motic BA310 microscope. The maximum BL and width of each prey item (maximum prey width, MPW) were measured with the microscope, a camera Motic moticam 2500 (resolution 5.0 M Pixel) and the software Motic Image Plus 2.0. The volume of each prey item was estimated using the three-dimensional shape that most closely resembled the item, following Cass-Calay (2003) and Sun \& Liu (2003). The prosome length of copepodite prey was measured since the urosome was often missing.

\section{Data AND Statistical anAlyses}

Hydrographic data (temperature, salinity, density), abundance of potential prey field (nauplii and copepodites), anchoveta larval abundance, and body length of larvae collected at different strata and tidal phase were compared with Mann-Whitney U tests, because data showed no normal distribution (ShapiroWilk test, $\mathrm{W}>0.559, P<0.01)$. Because of microzooplankton data were collected at 4 discrete depth, while the ichthyoplankton was collected at 2 integrated depths, the two shallower (surface and $5 \mathrm{~m}$ depth) and the two deeper (10 and $30 \mathrm{~m}$ depth) samples of microzooplankton were integrated to readily compared the prey field with the larval distribution and feeding selectivity.

All larvae with identifiable prey in their guts were used for the analysis. The relationships between BL and maximum width of the preys (MWP) were determined by linear regression analysis separately for each sampled stratum (0-10 m and 10-45 $\mathrm{m}$ depth) and between tidal phases; comparisons of MWP-at-size and slopes were done with one-way ANCOVA. The feeding incidence (FI) was calculated as a percentage of the total number of larvae that had gut contents out of the total number of larvae examined (Sassa \& Kawaguchi 2004). Comparisons of FI between strata (0-10 m, 10-45 m depth), and tidal phase (flood and ebb) were carried out with contingence tables.
The diet was described using the percent frequency of occurrence $(\% F)$ of a diet item in larvae with food in their guts, the percent of total number $(\% N)$ of diet items examined and the percent of volume $(\% \mathrm{~V})$ of each item out of the total volume of prey items. An index of relative importance (IRI) was calculated as follows: IRI $=(\% N+$ $\% V) \times \% F$. To readily allow comparisons among prey items, the IRI was the standardised to \%IRI for each prey item $i$ (Cortés 1997).

To determine the variation of feeding success of larval E. ringens between vertical strata and between tidal phases, 3 measures were compared: number of prey items per gut (NPPG, number), maximum prey width (MPW, mm) and total prey volume per gut (TVPG, $\mathrm{mm}^{3}$ ) (Reiss et al. 2002). Prior to analysis, all measurements were related with BL by simple regression models. If $\beta$ of the model was $\neq 0$, then comparisons between strata (0-10 vs. 10-45 $m$ depth strata) and between tidal phase (flood $v s$. ebb samples) were carried out by one-way ANCOVA; if $\beta$ did not differ from zero, Mann-Whitney $U$ tests were run to compare the feeding success between treatments of a factor.

For the prey selectivity analysis, the alpha index, $\alpha$ (Chesson 1978), was calculated as $\alpha_{\mathrm{i}}=\left(r_{\mathrm{i}} / p_{\mathrm{i}}\right) \Sigma^{m}{ }_{i=1}\left(r_{\mathrm{i}} / p_{\mathrm{i}}\right)^{-1}$ $(i=1, \ldots, m)$, where $r_{\mathrm{i}}$ and $p_{\mathrm{i}}$ are the percentage abundances of prey item $i$ in the larval diet and in the plankton samples, respectively. Only the three most common food organisms ingested were considered for the purpose of focussing on preferences for organisms that contributed most to the larval diet, rather than on absolute prey preference (Morote et al. 2011). The values of $\alpha_{i}$ range from 0 to 1 , with a critical (neutral) value of $1 / m$, higher values indicating preference and lower values rejection. As the index incorporates relative abundances of prey, it is unaffected by prey total abundance (Lechowicz 1982). Prey selectivity was calculated for individual larvae by prey type for 2 size classes: $<7 \mathrm{~mm}$ and $>7 \mathrm{~mm}$ BL.

\section{Results}

\section{Physical environment}

During the study period, two typical and noticeable layers were identified in the water column of Hornopirén inlet; a surface one, the mixed layer, characterised by warmer temperature $\left(10.47-15.63^{\circ} \mathrm{C}, 13.67 \pm 0.63^{\circ} \mathrm{C}\right)$, and lower salinity (12.67-31.38, 27.32 \pm 4.46$)$ and density (8.22-23.48 units of sigma-t, $19.60 \pm 3.74$ units of sigma-t), separated by a strong thermo- and halocline from the deep layer, 
with lower and stable water temperature $\left(10.49-13.97^{\circ} \mathrm{C}\right.$, $\left.11.53 \pm 1.02^{\circ} \mathrm{C}\right)$, and saltier $(19.83-32.47,31.81 \pm 0.95)$ and denser waters (14.37-24.90 units of sigma-t, $24.11 \pm 1.00$ units of sigma-t; Fig. 2). Throughout the days, there was an ascent of the thermocline; the isothermal of $12^{\circ} \mathrm{C}$ ascended from 34 to $12 \mathrm{~m}$ depth, and periodic warming of the surface layer occurred during daytime (Fig. 2). Both salinity and density showed high variation in the first 10 $\mathrm{m}$ depth, and they were keep largely stable conditions below $10 \mathrm{~m}$ depth. Fluctuations of the isopycnals were more evident in the first $10 \mathrm{~m}$ of the water column (Fig. 2), and it can be observed in the zoom image, the 18 units of sigma-t isopycnal showed near-tidal oscillations in depth, with vertical excursions of $\sim 2 \mathrm{~m}$ depth. The pattern of the water density field suggests the exit of lighter water parcels in the surface layer of the inlet during the ebb and intrusion of denser waters into the inlet during the flood. Differences of all physical parameters were significant between strata (temperature: $\mathrm{U}=7957, P<0.001$; salinity: $\mathrm{U}=4485, P<0.001$; density: $\mathrm{U}=3966, P<0.001$ ).

\section{MicrozooplankTON ABUNDANCE AND DISTRIBUTION}

The microzooplankton was composed by 27 different taxa. Suitable potential prey for larval anchoveta are indicated by asterisks in Table 1 (flood) and Table 2 (ebb). There were differences in the composition of the microzooplankton between tidal phases; during flood conditions, microzooplankton was composed of 27 taxa, but they reduced up to 24 taxa during ebb (Tables 1 and 2). Most taxa were highly abundant immediately below low surface salinity, at 5 and $10 \mathrm{~m}$ depth, and showed high temporal variability and did not show any clear
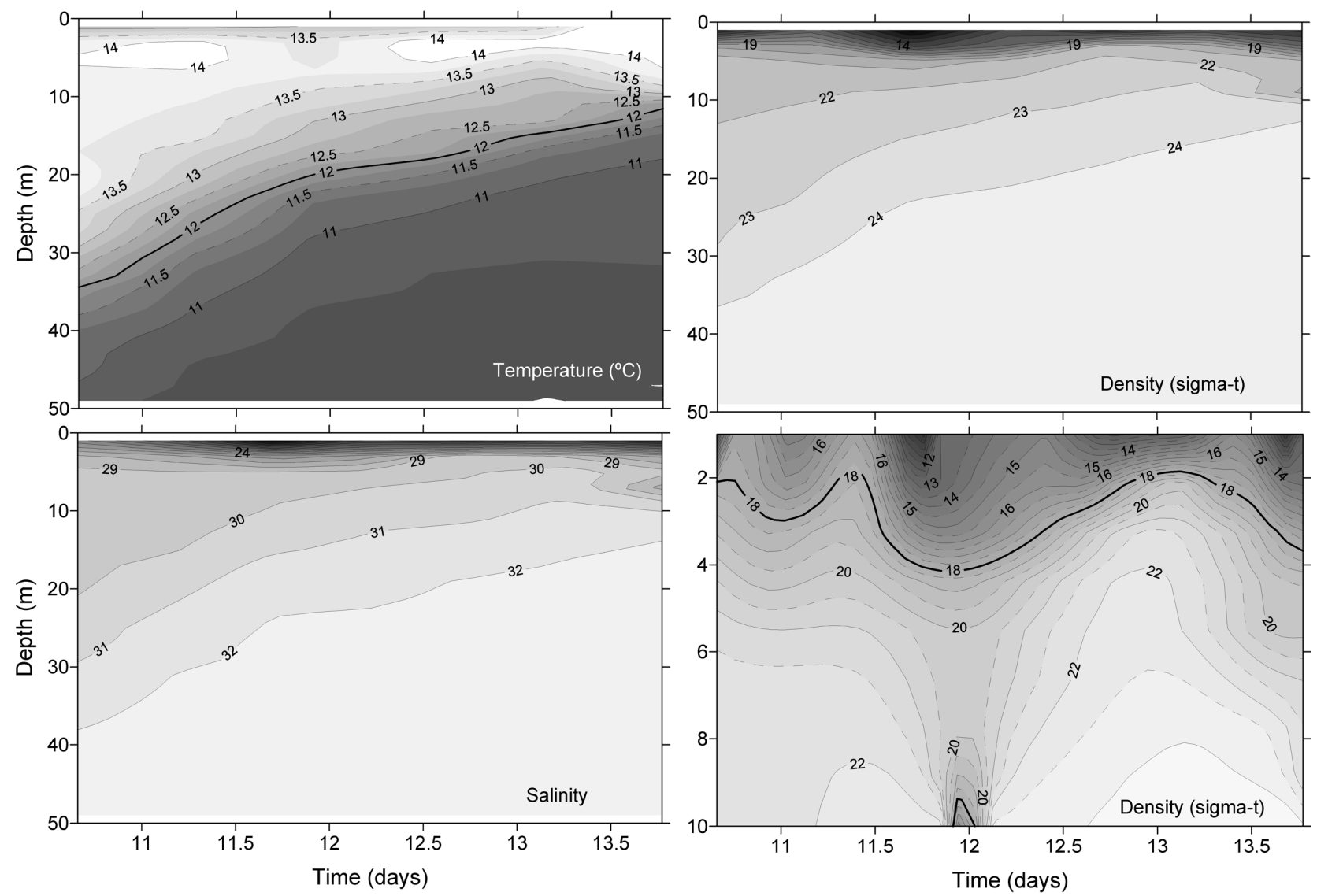

Figure 2. Environmental conditions (temperature, salinity and density) of the first $50 \mathrm{~m}$ depth of the water column of the Hornopirén inlet, during 10-13 December 2010 / Condiciones ambientales (temperatura, salinidad y densidad) de los primeros $50 \mathrm{~m}$ de profundidad de la columna de agua del canal Hornopirén, durante el 10-13 de diciembre de 2010 
Table 1. Composition and abundance (ind. $\mathrm{m}^{-3}$ ) of microzooplankton collected at different depths in flood conditions during 10-13 December 2010 at Hornopirén inlet, Chilean Patagonia. SD corresponds to one standard deviation; suitable potential prey for larval anchoveta are indicated by asterisks $(*)$ / Composición y abundancia (ind. $\mathrm{m}^{-3}$ ) del microzooplancton recolectado a diferentes profundidades en condiciones de llenante durante el 10-13 de diciembre de 2010 en canal Hornopirén, Patagonia chilena. SD corresponde a una desviación estándar; las presas potenciales de las larvas de anchoveta están indicadas con asterisco $\left({ }^{*}\right)$

\begin{tabular}{|c|c|c|c|c|c|c|c|c|c|c|c|c|}
\hline & \multicolumn{3}{|c|}{$0 \mathrm{~m}$} & \multicolumn{3}{|c|}{$5 \mathrm{~m}$} & \multicolumn{3}{|c|}{$10 \mathrm{~m}$} & \multicolumn{3}{|c|}{$30 \mathrm{~m}$} \\
\hline & Median & Mean & SD & Median & Mean & SD & Median & Mean & SD & Median & Mean & SD \\
\hline Acartia tonsa & 1200 & 1511 & 1338 & 8000 & 8543 & 4595 & 8600 & 8086 & 4217 & 3800 & 6167 & 4657 \\
\hline Calanoides patagoniensis & 200 & 200 & - & - & - & - & - & - & - & 400 & 400 & - \\
\hline Centropages brachiatus & - & - & - & - & - & - & 1000 & 1000 & - & - & - & - \\
\hline Eucalanus sp. & - & - & - & - & - & - & 1200 & 1200 & - & - & - & - \\
\hline Paracalanus sp. & 1600 & 1750 & 1330 & 2000 & 2400 & 2582 & 1500 & 1533 & 891 & 1200 & 1920 & 1653 \\
\hline Pleuromamma sp. & 200 & 200 & - & 200 & 200 & - & 400 & 400 & - & 1400 & 1400 & - \\
\hline Rhincalanus nasutus & - & - & - & 600 & 600 & 283 & 600 & 600 & - & - & - & - \\
\hline *Oithona spp. & 200 & 400 & 400 & 3200 & 4133 & 3590 & 2600 & 2567 & 1113 & 2200 & 2467 & 1484 \\
\hline *Microsetella sp. & 200 & 200 & - & - & - & - & - & - & - & - & - & - \\
\hline *Oncaea sp. & 200 & 200 & 0 & - & - & - & - & - & - & - & - & - \\
\hline *Calanoid copepodites & 600 & 833 & 528 & 5800 & 6943 & 3487 & 8600 & 10086 & 7316 & 8400 & 6943 & 2274 \\
\hline * Nauplii & 500 & 500 & 424 & 800 & 1067 & 1001 & 1000 & 840 & 518 & 800 & 1000 & 909 \\
\hline Copepod moults & 1500 & 1467 & 787 & 1200 & 1257 & 1031 & 1500 & 1933 & 1950 & 800 & 1120 & 687 \\
\hline Hydromedusa & - & - & - & 200 & 200 & 0 & 500 & 500 & 115 & 400 & 400 & - \\
\hline Siphonophora & - & - & - & - & - & - & 200 & 333 & 231 & - & - & - \\
\hline Sagitta spp. & - & - & - & - & - & - & 200 & 200 & 0 & 200 & 200 & - \\
\hline *Cladocera & - & - & - & 200 & 200 & - & - & - & - & 1000 & 1000 & - \\
\hline *Ostracoda & 200 & 200 & - & 200 & 467 & 462 & 200 & 200 & 0 & 200 & 200 & - \\
\hline Amphipoda & 200 & 200 & 0 & 200 & 200 & - & - & - & - & - & - & - \\
\hline *Oikopleura sp. & - & - & - & 1600 & 1943 & 1355 & 1400 & 1520 & 701 & 600 & 680 & 335 \\
\hline Stomatopoda & 200 & 200 & 0 & 200 & 200 & - & - & - & - & - & - & - \\
\hline *Bivalvia larvae & 300 & 300 & 141 & 600 & 533 & 207 & 1000 & 1000 & 548 & 400 & 450 & 300 \\
\hline *Pluteus larvae & - & - & - & 200 & 200 & 0 & 200 & 300 & 200 & 400 & 333 & 115 \\
\hline$*$ Zoea & 600 & 600 & 566 & 500 & 550 & 191 & 200 & 267 & 103 & 200 & 200 & 0 \\
\hline * Polychaeta larvae & 400 & 400 & 0 & 200 & 250 & 100 & 200 & 267 & 115 & 300 & 300 & 141 \\
\hline Fish eggs (Clupeidae) & 400 & 400 & 200 & 400 & 400 & 200 & 200 & 1267 & 1848 & 300 & 300 & 141 \\
\hline Fish eggs (Engraulis ringens) & 200 & 200 & - & 200 & 200 & - & - & - & - & - & - & - \\
\hline
\end{tabular}

pattern associated to the tidal cycle (Fig. 3). Copepods (adults, copepodites and nauplii) dominated the composition of microzooplankton. Total nauplii varied in abundance from 0 to 2800 ind. $\mathrm{m}^{-3}\left(822 \pm 736\right.$ ind. $\left.\mathrm{m}^{-3}\right)$, and reduced its abundance when denser waters occurred in surface and subsurface waters (Figs. 3 and 4). However, non parametric tests did not detect significant differences between strata $(U=41.5, P=0.543)$ nor between tidal phases $(\mathrm{U}=33, P=0.321)$. Copepodites were largely abundant throughout the studied period and among depths (range: $0-26200$ ind. $\mathrm{m}^{-3} ; 5930 \pm 4737$ ind. $\mathrm{m}^{-3}$ ), except in the surface (Fig. 4); its abundance was larger in the deep layer $(\mathrm{U}=20, P=0.001)$ and during flood $(\mathrm{U}=39$, $P=0.045)$.

\section{Distribution, ABUndance AND LENGTh of LARVAL ANCHOVY}

Engraulis ringens larvae were the most abundant taxon in the plankton samples from Hornopirén inlet during December 2010. A total of 1090 larvae were collected during 10-13 December (31.91\% of the whole ichthyoplankton), varying from 14.93 to 781.56 ind. $1000 \mathrm{~m}^{-3}$ (mean \pm standard deviation, $199.78 \pm 159.78$ ind. $1000 \mathrm{~m}^{-3}$, median: 173.33 
Table 2. Composition and abundance (ind. $\mathrm{m}^{-3}$ ) of microzooplankton collected at different depths in ebb conditions during 10-13 December 2010 at Hornopirén inlet, Chilean Patagonia. SD corresponds to one standard deviation; suitable potential prey for larval anchoveta are indicated by asterisks $(*)$ / Composición y abundancia (ind. $\mathrm{m}^{-3}$ ) del microzooplancton recolectado a diferentes profundidades en condiciones de vaciante durante el 10-13 de diciembre de 2010 en canal Hornopirén, Patagonia chilena. SD corresponde a una desviación estándar; las presas potenciales de las larvas de anchoveta están indicadas con asterisco $\left({ }^{*}\right)$

\begin{tabular}{|c|c|c|c|c|c|c|c|c|c|c|c|c|}
\hline & \multicolumn{3}{|c|}{$0 \mathrm{~m}$} & \multicolumn{3}{|c|}{$5 \mathrm{~m}$} & \multicolumn{3}{|c|}{$10 \mathrm{~m}$} & \multicolumn{3}{|c|}{$30 \mathrm{~m}$} \\
\hline & Median & Mean & SD & Median & Mean & SD & Median & Mean & SD & Median & Mean & SD \\
\hline Acartia tonsa & 900 & 950 & 661 & 3300 & 4100 & 1949 & 6200 & 5667 & 2248 & 1700 & 1750 & 1330 \\
\hline Centropages brachiatus & 1000 & 1000 & 1131 & - & - & - & - & - & - & 200 & 200 & 0 \\
\hline Eucalanus sp. & - & - & - & - & - & - & - & - & - & 200 & 200 & - \\
\hline Paracalanus sp. & 400 & 400 & 163 & 800 & 1867 & 2386 & 400 & 467 & 115 & 2600 & 2800 & 1523 \\
\hline Pleuromamma sp. & - & - & - & - & - & - & 200 & 200 & - & 500 & 500 & 424 \\
\hline Rhincalanus nasutus & 1800 & 1800 & 2263 & - & - & - & - & - & - & 200 & 200 & - \\
\hline *Oithona spp. & 900 & 900 & 990 & 1600 & 2067 & 987 & 2000 & 2133 & 1804 & 1700 & 1700 & 1065 \\
\hline *Microsetella sp. & 200 & 200 & - & 200 & 200 & - & - & - & - & 800 & 800 & - \\
\hline *Oncaea sp. & 1600 & 1600 & - & - & - & - & - & - & - & 600 & 600 & 566 \\
\hline *Calanoid copepodites & 400 & 533 & 416 & 8200 & 7500 & 4190 & 5600 & 5067 & 1474 & 5600 & 5867 & 643 \\
\hline * Nauplii & 400 & 333 & 115 & 200 & 867 & 1155 & 200 & 600 & 693 & 1200 & 1200 & - \\
\hline Copepod moults & 1800 & 2480 & 2508 & 1200 & 1200 & 800 & 1400 & 1400 & 1131 & 500 & 700 & 476 \\
\hline Hydromedusa & 200 & 200 & 0 & 200 & 200 & 0 & 200 & 200 & - & 200 & 200 & - \\
\hline Siphonophora & - & - & - & - & - & - & 200 & 200 & - & 200 & 200 & - \\
\hline Sagitta spp. & - & - & - & - & - & - & 600 & 600 & - & - & - & - \\
\hline *Ostracoda & 200 & 200 & 0 & 200 & 200 & 0 & - & - & - & 200 & 200 & - \\
\hline Amphipoda & 200 & 200 & - & - & - & - & - & - & - & - & - & - \\
\hline *Oikopleura sp. & - & - & - & 800 & 850 & 300 & 400 & 400 & 0 & 300 & 300 & 141 \\
\hline Stomatopoda & 200 & 200 & - & - & - & - & - & - & - & - & - & - \\
\hline *Bivalvia larvae & 200 & 200 & - & 200 & 200 & 0 & 1000 & 1000 & 283 & 1100 & 1100 & 990 \\
\hline *Pluteus larvae & 200 & 200 & - & - & - & - & 200 & 200 & 0 & 200 & 200 & - \\
\hline *Zoea & 400 & 400 & 200 & 400 & 333 & 115 & 600 & 600 & 566 & 400 & 400 & - \\
\hline *Polychaeta larvae & 200 & 200 & - & 200 & 200 & - & 200 & 200 & - & - & - & - \\
\hline Fish eggs (Clupeidae) & 200 & 200 & - & - & - & - & - & - & - & - & - & - \\
\hline
\end{tabular}

ind. $1000 \mathrm{~m}^{-3}$ ) (Fig. 4). There was no significant differences in the abundance between strata (Mann-Whitney $\mathrm{U}$ test, $\mathrm{U}=188, P=0.745)$ nor between tides $(\mathrm{U}=170, P=0.446)$. Larval size ranged from 2.54 to $15.07 \mathrm{~mm}$ BL $(6.00 \pm 1.72$ $\mathrm{mm} \mathrm{BL}, n=572)$. Larvae collected in the mixed layer (0-10 $\mathrm{m}$ depth) were significant larger $(6.25 \pm 1.80 \mathrm{~mm})$ than those collected in the deep layer (10-45 m depth, $5.76 \pm$ $1.59 \mathrm{~mm})(\mathrm{U}=34992, P=0.002)$, but body length did not vary during both tidal phases $(\mathrm{U}=35026, P=0.117)$.

\section{FEEDING INCIDENCE AND LARVAL DIET}

The diet of larval E. ringens was based in the analysis of 486 gut contents (size range 2.54-15.02 mm BL). From those, only 95 larvae had any content in its guts $(\mathrm{FI}=19.51 \%)$. There was no differences in the FI between strata (0-10 m: $\left.\mathrm{FI}=19.69 \% ; 10-45 \mathrm{~m}: \mathrm{FI}=19.31 \% ; \chi^{2}=0.011, P=0.918\right)$; however, FI was higher in larvae captured during flood (FI= 25.09\%) than ebb $\left(\mathrm{FI}=11.94 \%, \chi^{2}=12.9, P<0.001\right)$. Also, larvae fed mostly during day hours $(\mathrm{FI}=26.66 \%)$ than night $\left(\mathrm{FI}=2.11 \%, \chi^{2}=38.6, P<0.001\right)$. The diet of $E$. ringens larvae collected during 4 consecutive days was composed of 13 different prey items, mainly nauplii, calanoid and harpacticoid copepodites, and dinoflagellate cysts (Table 3). Numerically, nauplii, chitinous remains and dinoflagellate cysts were the most important prey items; volumetrically, nauplii and copepodites of the large calanoid copepod Rhincalanus nasutus were the most relevant taxa (Table 3). The most frequent prey items in the guts were nauplii, chitinous remains and Microsetella copepodites. In all conditions (flood, ebb, mixed and deep layers), nauplii represented more than $70 \%$ of the gut content, followed by copepodites (Fig. 5). 
Table 3. Diet of the larval Engraulis ringens collected during 10-13 December 2010 in Hornopirén inlet. \%N correspond to the percent of the total number of prey items, \%V correspond to the percent of the total volume of prey items, and \% $\mathrm{F}$ the percent frequency of the occurrence of a diet item among larvae with food in their guts. \%IRI correspond to the index of relative importance as percentage / Dieta de larvas de Engraulis ringens recolectadas durante el 10-13 de diciembre de 2010 en el canal Hornopirén. \%N corresponde al porcentaje del número total de items presa, \% $\mathrm{V}$ corresponde al porcentaje del volumen total de ítems presa, y \% $\mathrm{F}$ a la frecuencia porcentual de la ocurrencia de un ítem dietario entre las larvas con contenido en sus estómagos. \%IRI corresponde al índice de importancia relativa como porcentaje

\begin{tabular}{lrrrr}
\hline Taxa & $\% \mathrm{~N}$ & $\% \mathrm{~V}$ & $\% \mathrm{~F}$ & $\% \mathrm{IIR}$ \\
\hline Ceratium furca & 1.67 & 0.34 & 1.85 & 0.052 \\
Dinoflagellate cyst & 10.56 & 0.11 & 0.93 & 0.155 \\
Nauplii & 60.00 & 47.63 & 60.19 & 91.878 \\
Copepodite & 2.22 & 2.30 & 2.78 & 0.160 \\
Copepodite (Rhincalanus nasutus) & 0.56 & 25.86 & 0.93 & 0.211 \\
Copepodite (Acartia tonsa) & 0.56 & 0.50 & 0.93 & 0.011 \\
Copepodite (Centropages brachiatus) & 0.56 & 1.71 & 0.93 & 0.021 \\
\hline
\end{tabular}

\begin{tabular}{lrrrr}
\hline Taxa & $\% \mathrm{~N}$ & $\% \mathrm{~V}$ & $\% \mathrm{~F}$ & $\% \mathrm{IIR}$ \\
\hline Copepodite (Pleurommama gracilis) & 0.56 & 2.46 & 0.93 & 0.027 \\
Calanoid copepodite & 0.56 & 0.89 & 0.93 & 0.014 \\
Copepodite (Microsetella sp.) & 3.33 & 6.29 & 5.56 & 0.561 \\
Crustacean zoea & 0.56 & 0.14 & 0.93 & 0.008 \\
Crustacean remains & 2.78 & 1.10 & 4.63 & 0.226 \\
Chitinous remains & 16.11 & 10.65 & 18.52 & 6.675 \\
& & & & \\
\hline
\end{tabular}
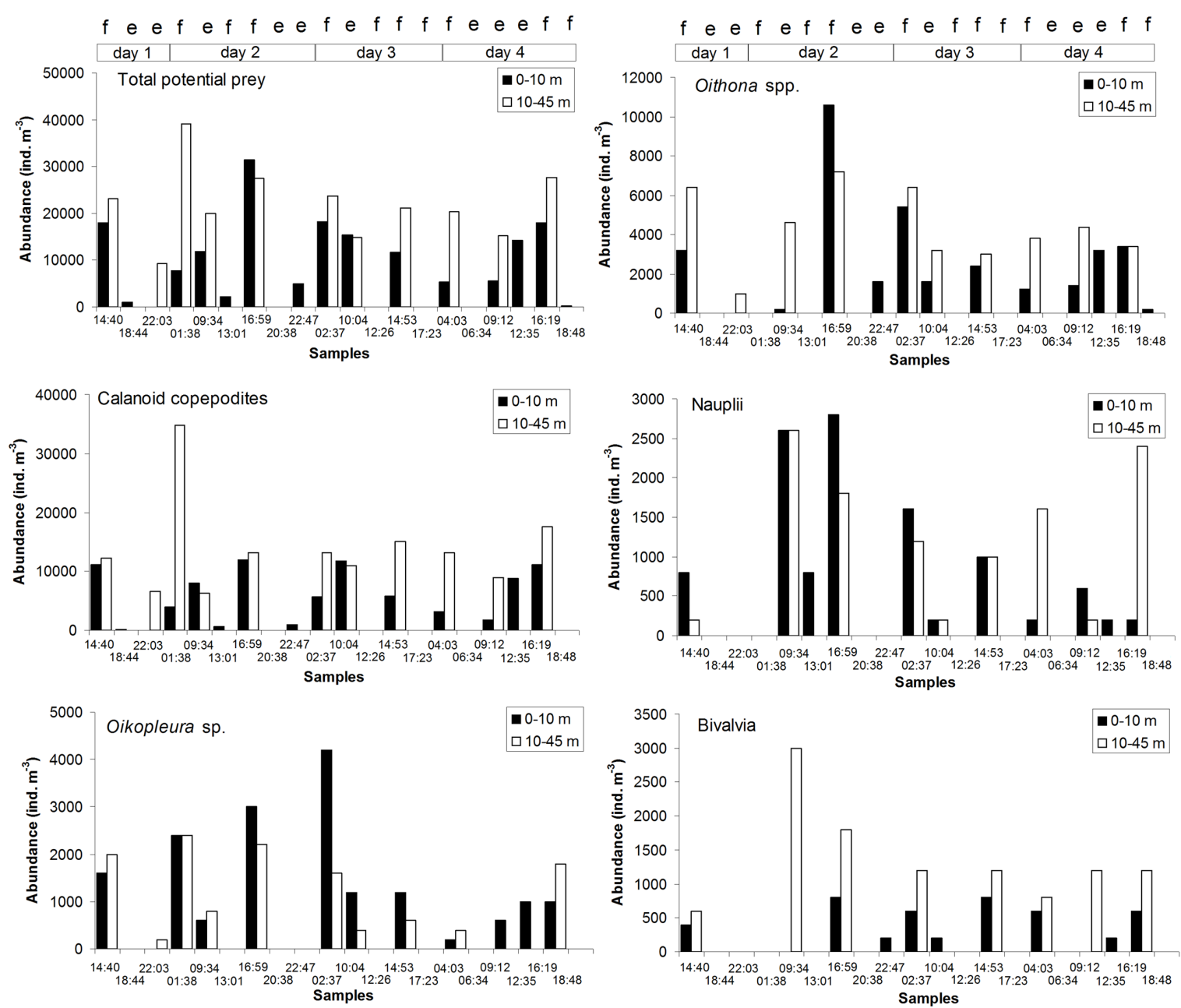

Figure 3. Abundance of potential prey field (microzooplankton) (ind. $\mathrm{m}^{-3}$ ) during the study period in Hornopirén inlet, northern Patagonia. $\mathbf{e}=\mathbf{e b b}, \mathbf{f}=$ flood $/$ Abundancia del campo de presas potencial (microzooplancton) (ind. $\mathrm{m}^{-3}$ ) durante el periodo de studio en canal Hornopirén, Patagonia norte. $e=$ vaciante, $f=$ llenante 

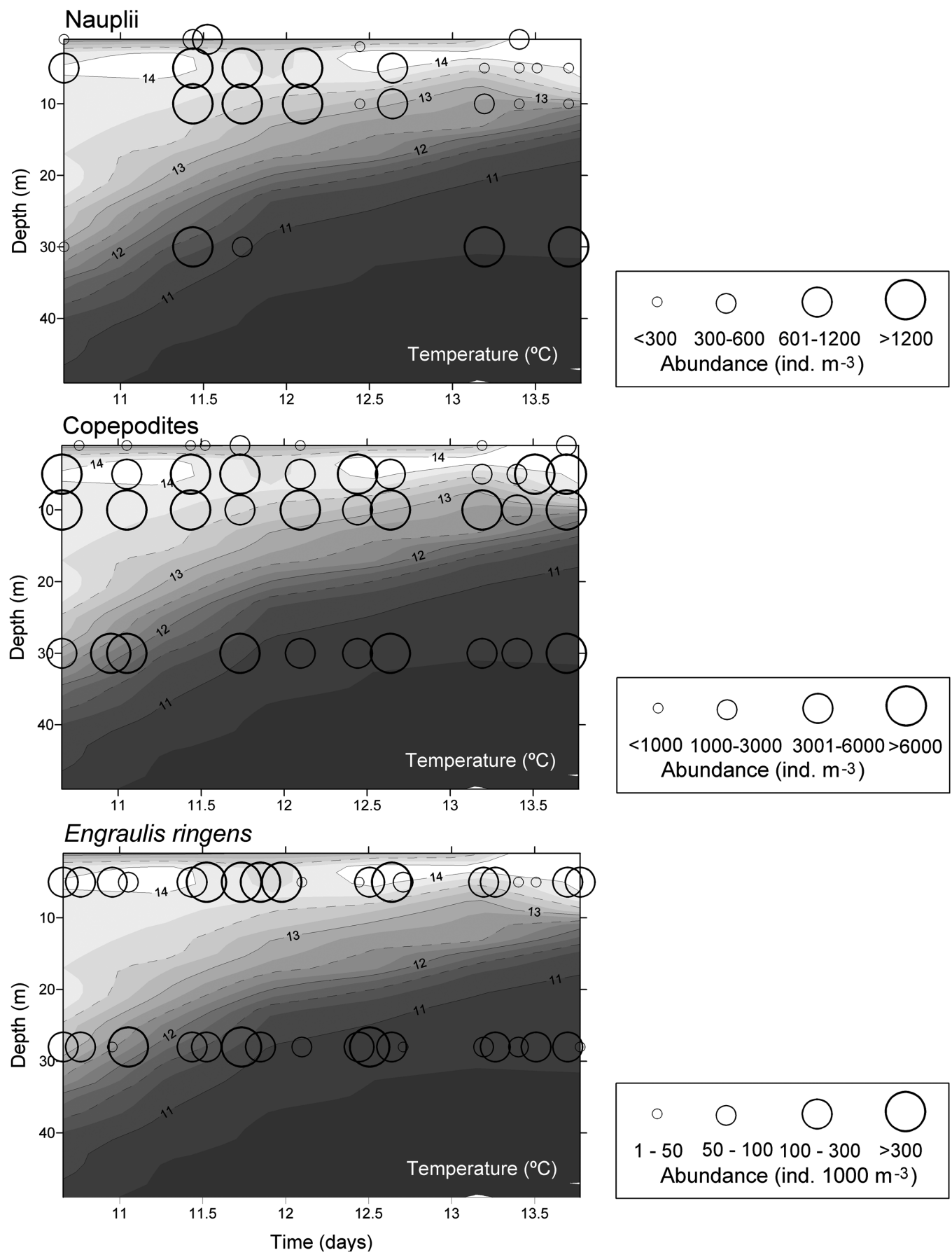

Figure 4. Vertical distribution of total nauplii, copepodites (ind. $\mathrm{m}^{-3}$ ) and larval anchoveta Engraulis ringens (ind. $1000 \mathrm{~m}^{-3}$ ) in Hornopirén inlet, northern Patagonia. Overimposed is the temperature conditions of the water column / Distribución vertical de nauplii totales, copepoditos (ind. $\mathrm{m}^{-3}$ ) y larvas de anchoveta Engraulis ringens (ind. $1000 \mathrm{~m}^{-3}$ ) en el canal Hornopirén, Patagonia norte. Superimpuesta están las condiciones de temperatura de la columna de agua 

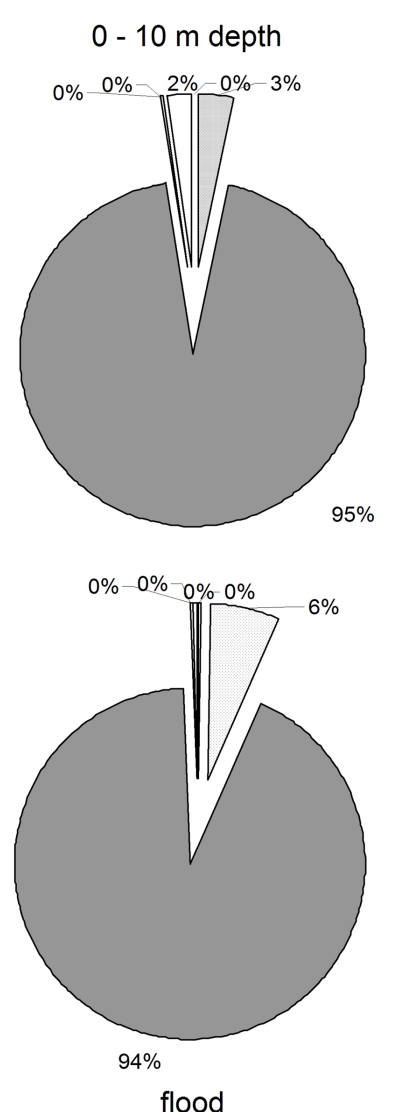
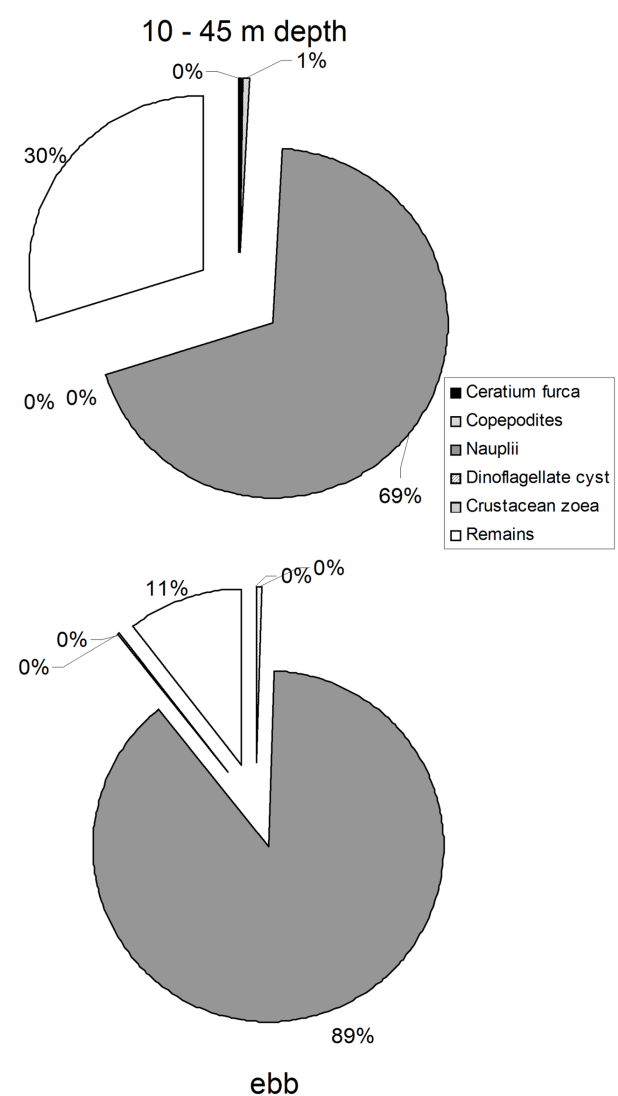

Figure 5. Index of relative importance (\%IRI) of the diet of larval Engraulis ringens by strata and tidal phase / Índice de importancia relativa (\%IRI) de la dieta de larvas de anchoveta Engraulis ringens por estrato y fase mareal

\section{FeEding SUCCESS AND SELECTIVITY}

A total of 181 prey items were identified in the gut contents. The smallest prey item recorded in larval $E$. ringens was small nauplius $(15.18 \mu \mathrm{m}$ width) in a larva measuring $6.43 \mathrm{~mm} \mathrm{BL}$, and the largest prey was a Rhincalanus nasutus copepodite $(267.37 \mu \mathrm{m}$ width) in a larva that measured $10.46 \mathrm{~mm}$ BL (Fig. 6). The number of prey items per gut ranged from 0 to $19(1.89 \pm 2.07$, excluding zeros). There was no significant increase or decrease of NPPG during the larval development (oneway ANCOVA, F= 3.42, $P=0.067$ ) (Table 4, Fig. 6). Larval anchoveta collected in the deep stratum had higher number of prey items per gut $(2.35 \pm 2.79$ prey) than those collected in the mixed layer $(1.48 \pm 0.89$ prey $)(\mathrm{U}=771, P=$ $0.008)$, but it did not differ between tidal phases $(\mathrm{U}=652$, $P=0.086)$.
Total volume per gut varied from $6.85 \times 10^{-5}$ to 0.029 $\mathrm{mm}^{3}$ (Fig. 6). There was a slight but significant increase in the TVPG along larval growth $(\mathrm{F}=14.76, P<0.001$, Table $4)$. Adjusted linear models for each stratum and tidal phase are showed in Table 4. No significant effects of the hydrographic features of the water column structure (oneway ANCOVA, $\mathrm{F}=1.01, P=0.317)$ nor the tidal phase $(\mathrm{F}=$ $1.48, P=0.227$ ) over the TVPG were detected.

There was a significant increase in the prey size during the larval development $(\mathrm{F}=37.05, P<0.001$, Table 4), although the model only explained $17.2 \%$ of the data. When the relationship between prey size and body length was compared between strata, those larval anchoveta collected in the mixed layer predates over larger preys than those collected in the deep strata (one-way ANCOVA, 
Table 4. Linear regressions of body length (BL) of larval anchoveta in relation to their feeding success. NPPG= number of prey per gut; TVPG= total volume of prey per gut; MPW= maximum prey width. $\alpha=$ intercept, $\beta=$ slope, $\mathrm{SE}=$ standard error. For TVPG and M PW, models are given by stratum and tidal phase; significant regressions ( $P$ ) indicated by bold numbers / Regresiones lineales de la longitud corporal (BL) de larvas de anchovera en relación a su éxito alimentario. NPPG= número de presas por estómago; TVPG= volumen total de presas por estómago; MPW= ancho máximo de la presa. $\alpha=$ intercepto, $\beta=$ pendiente, $S E=$ error estándar. Para TVPG y MPW, los modelos son entregados por estrato y fase mareal; las regresiones significativas $(P)$ son indicadas con negrita

\begin{tabular}{rccccccr}
\hline & $\alpha$ & SE & $\beta$ & SE & $\mathrm{r}^{2}$ & F & $P$ \\
\hline BL vs NPPG & 3.69 & 0.99 & -3.00 & 0.16 & 0.035 & 3.42 & 0.067 \\
BL vs TVPG & -0.004 & 0.001 & $8.01 \times 10^{-4}$ & $2.31 \times 10^{-4}$ & 0.137 & 14.76 & $<\mathbf{0 . 0 0 1}$ \\
Mixed layer & -0.0061 & 0.0022 & 0.0012 & $3.66 \times 10^{-4}$ & 0.200 & 12.02 & $\mathbf{0 . 0 0 1}$ \\
Deep layer & $1.0 \times 10^{-5}$ & $7.59 \times 10^{-4}$ & $1.59 \times 10^{-4}$ & $1.23 \times 10^{-4}$ & 0.037 & 1.65 & 0.205 \\
Flood & $4.72 \times 10^{-4}$ & $4.87 \times 10^{-4}$ & $7.3 \times 10^{-5}$ & $8.1 \times 10^{-5}$ & 0.011 & 0.81 & 0.373 \\
Ebb & -0.011 & 0.004 & 0.0021 & $6.49 \times 10^{-4}$ & 0.316 & 10.17 & $\mathbf{0 . 0 4 2}$ \\
BL vs MPW $\quad 10.63$ & 9.53 & 9.91 & 1.63 & 0.172 & 37.05 & $<\mathbf{0 . 0 0 1}$ \\
Mixed layer & 34.28 & 18.31 & 6.84 & 3.06 & 0.065 & 5.01 & $\mathbf{0 . 0 2 8}$ \\
Deep layer & -2.59 & 9.83 & 11.53 & 1.70 & 0.306 & 45.83 & $<\mathbf{0 . 0 0 1}$ \\
Flood & 17.31 & 9.81 & 8.35 & 1.71 & 0.141 & 23.77 & $<\mathbf{0 . 0 0 1}$ \\
Ebb & 2.47 & 30.11 & 12.56 & 4.67 & 0.188 & 7.22 & $\mathbf{0 . 0 1 1}$ \\
\hline
\end{tabular}

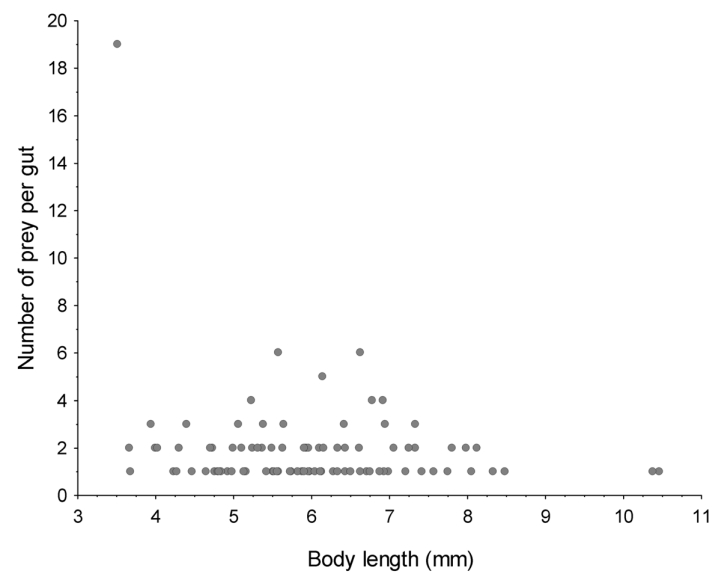

Figure 6. Estimators of feeding success in larval Engraulis ringens from Hornopirén inlet, during December 2010. Number of prey per gut, total volume prey per gut $\left(\mathrm{mm}^{3}\right)$ and maximum prey width $(\mu \mathrm{m})$ by body length $(\mathrm{mm} \mathrm{BL})$ / Estimadores de éxito alimentario en larvas de Engraulis ringens del canal Hornopirén, durante diciembre de 2010. Número de presas por estómago, volumen total de presas por estómago $\left(\mathrm{mm}^{3}\right)$ y ancho máximo de presas $(\mu \mathrm{m})$ por longitud corporal $(\mathrm{mm} \mathrm{BL})$
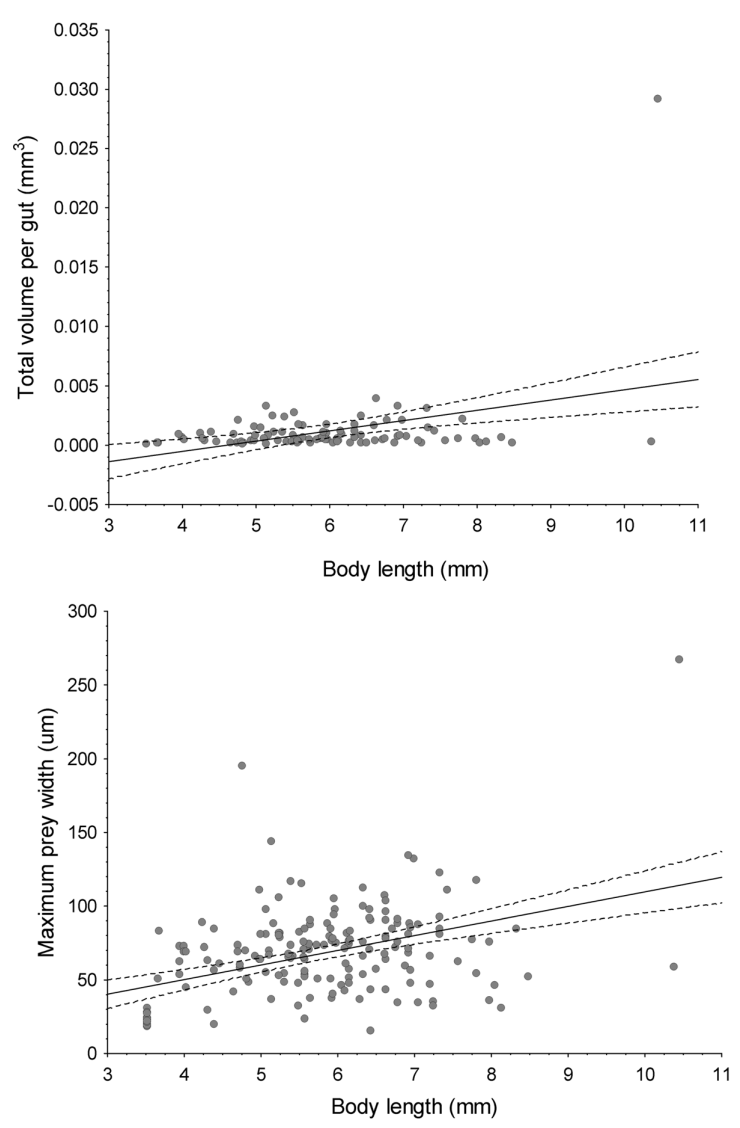

Vol. 49, № 3, 2014 

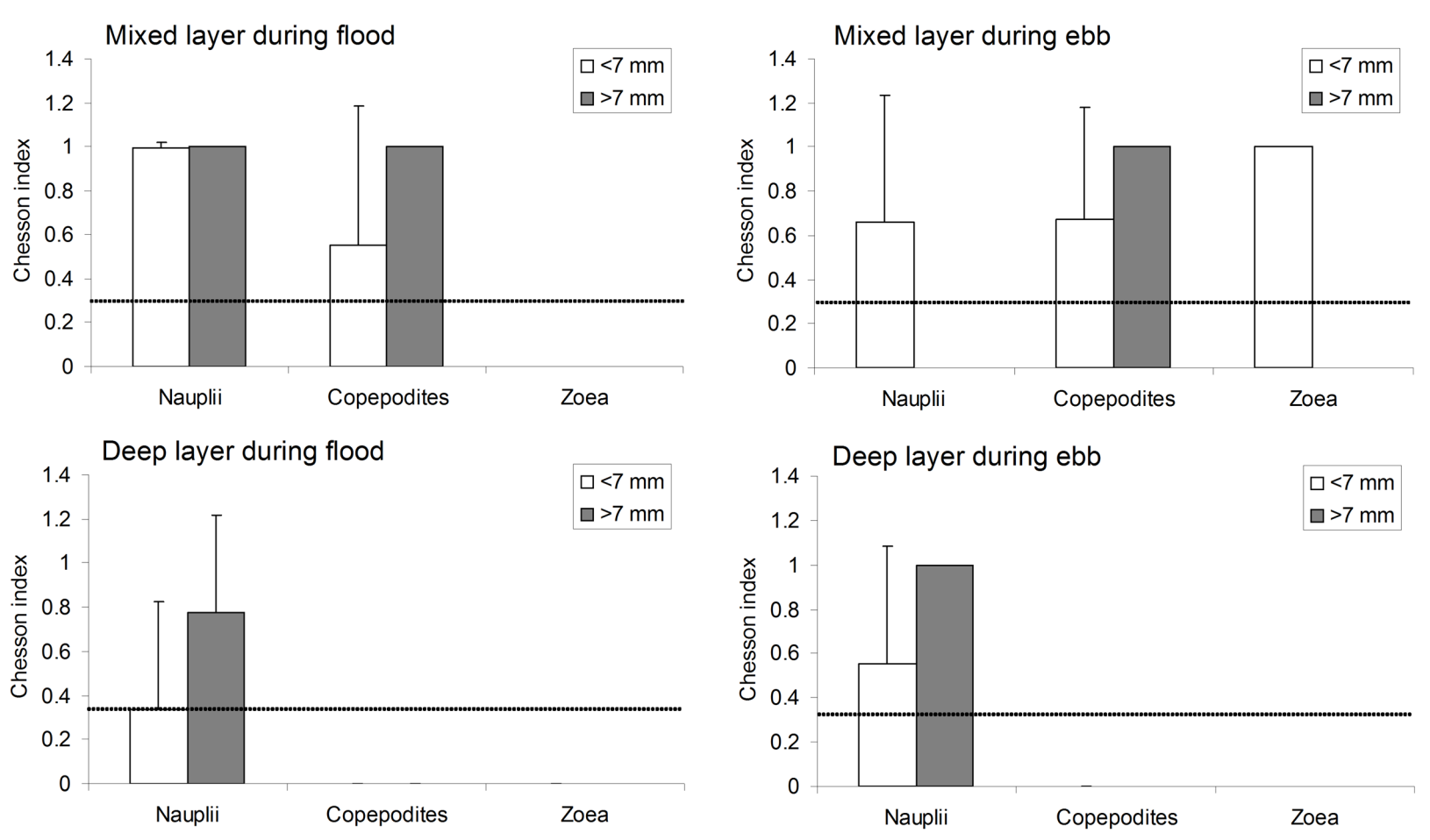

Figure 7. Prey selectivity (Chesson index, $\alpha$ ) of larval Engraulis ringens in Hornopirén inlet, southern Chile. Dotted line corresponds to the neutral selectivity / Selectividad de presas (índice Chesson, $\alpha$ ) de larvas de Engraulis ringens en el canal Hornopirén, sur de Chile. La línea punteada corresponde a la selectividad neutral

$\mathrm{F}=4.99, P=0.026)$, but no differences arose between tides $(\mathrm{F}=3.76, P=0.054)$. Because the relationship between prey size and BL was weak, more experiments should be done in the future for a robust result.

Prey selectivity of larval anchoveta change between layers of the water column and tides (Fig. 7). Larval $E$. ringens of all sizes positively select nauplii and copepodites in the mixed layer during flood, but during ebb conditions, large larvae tend to select copepodites as the preferred prey. On the other hand, in the deep layer only nauplii were positively selected during flood and ebb tidal phases (Fig. 7), although during flood the Chesson value for nauplii was near to the limit value (0.33).

\section{Discussion}

In a fjord-like environment of the Chilean Patagonia, the two most important oceanographic features, the hydrographic conditions of the 2 vertical layers, and the tides, affected the composition of microzooplankton, and the feeding incidence, success and selectivity of the larval anchoveta Engraulis ringens, but not their vertical distribution or abundance. Of both oceanographic factors, the hydrographic conditions of the vertical layers seem to have more biological consequences than tidal variations. Only abundance of copepodites in the field and the feeding incidence of E. ringens varied significantly within the tides, being larger during the flood.

The most important prey for larval E. ringens, the copepod nauplii, was collected in similar abundance throughout the study period. Also, the feeding incidence and the total prey volume ingested by larvae were the same in the brackish, mixed layer and the saltier, deep layer. Nonetheless, trophic interactions were different in order to obtain similar prey volume in the guts of larval $E$. ringens. In the upper, brackish and warmer water, larval E. ringens ingested less prey but of larger size, selecting nauplii and copepodites as the main prey items. On the other hand, in the deep, saltier and colder water, larvae ingested more prey of smaller size, showing only selectivity for nauplii. 
Low feeding incidence was found in the guts of larval E. ringens $(\sim 20 \%)$. This pattern also has been observed in larval anchovies and sardines (Engraulis encrasicolus, 20-30\%, Conway et al. 1998, Catalan et al. 2010, Morote et al. 2010, E. anchoita, 29-52\%, De Ciechomski 1967, Vasconcellos et al. 1998, Sardina pilchardus, 31.7\%, Morote et al. 2010), irrespective of the environment where they were collected. This may be due because clupeoid larvae are particularly susceptible to evacuation (regurgitation or defecation) in their gut contents during sampling and preservation (Arthur 1976). Additionally, clupeoid larvae have short gut evacuation rates. For example, Herrera \& Balbontín (1983) estimated a gut evacuation time of 3-10 h for larval Sardinops sagax, with a reduction in time along the larval development. Conway et al. (1998) suggested for larval E. encrasicolus a rapid gut clearance to explain the high percentage of empty guts. In our case, although low, the feeding incidence increased twice during the flood. This pattern is not affected by time of the day, because most larvae studied in the gut content analysis were collected during day hours (92 out of 95 larvae with content in its guts). Indirectly, change of tides may vary the water column turbidity, and suspensions may enhance feeding by providing visual contrast of prey items on the small perceptive scale used by the larvae (Boehlert \& Morgan 1985).

Larval stages of Engraulis fed mostly on a mixture of phytoplankton and copepod stages (eggs, nauplii, copepodites) (Tudela et al. 2002, Morote et al. 2010, Sato et al. 2011). The prey composition and size range of ingested prey by larval E. ringens in this study was similar to those described by Llanos et al. (1996) and YáñezRubio et al. (2011) for larval E. ringens from central Chile. Larvae at both locations predate mainly over copepod nauplii and copepodites and dinoflagellates (Ceratium furca); nevertheless, larval anchoveta from the upwelling areas (central Chile) are more diverse in prey items (bivalve larvae, grain pollen, copepod eggs, Diplopsalis, Protoperidinium sp.) than those from the fjord areas. Therefore, prey size preferences during larval stage of the anchoveta are similar in upwelling and fjord ecosystems of the South Pacific.

Differences in sea water density between vertical layers may have some effects in the selection of prey for larval E. ringens, because of the swimming capabilities of microzooplankton. Microzooplankton in lighter sea water parcels may increase their locomotory patterns because it is less viscous. Naupliar stages of calanoid copepods swim in an irregular pattern with rapid jumps covering several body lengths separated by several seconds of slow swimming behaviour or non-swimming periods during which they sink slightly. In contrast, naupliar stages of cyclopoid copepods have a swimming pattern that is characterised by much longer periods of nonswimming (up to 30-40 s) (Buskey et al. 1993). In general, the prey becomes more easily detected, either visually or vibrationally, with increased activity. The type of motion (e.g., pulsed $v s$. constant swimming) may also be important as a clue (Govoni et al. 1986). Therefore, these behaviours may have impact on prey selectivity of larval E. ringens.

Previous reports have shown changes in prey selectivity of fish larvae along ontogeny (Llanos-Rivera et al. 2004, Morote et al. 2010), associated to changes in prey density (Schmitt 1986) and prey visibility (Peterson $\&$ Ausubel 1984), but there are scarce reports about changes in selectivity associated to oceanographic features. In our study, selectivity was large for nauplii in the mixed layer compared to the deep layer. When fish larvae are eating mainly the prey type that is more highly available, like nauplii seem to be in this case, that doesn't mean that there is an actual preference towards that prey type, but simply it is more convenience. Fish larvae prefer bigger and/or more energetic prey, in order for the larvae to optimize their efforts. However, whenever there are not highly energetic prey available, larvae would feed on anything that is easy to catch, i.e., the most abundant prey. Similarly, Dower et al. (1998) described that larval radiated shanny (Ulvaria subbifurcata) contained significantly fewer items in their guts on high-turbulence days, and these prey items were significantly larger that those found on low-turbulence days. Then, turbulence and sea water density may affect the size selectivity of larval E. ringens.

\section{ACKNOWLEDGMENTS}

We appreciate the field work of N. Suárez-Donoso, C. Cortes, S. Zepeda and J.E. Contreras, and the lab work of P. Contreras (Universidad de Concepción) in the analysis of microzooplankton. Two anonymous reviewers improved an early version of the ms. This research was supported by Comisión Nacional de Ciencia y Tecnología (CONICYT) [grant FONDECYT 11090020 to MFL]. 


\section{LITERATURE CITED}

Arthur DK. 1976. Food and feeding of larvae of three fishes occurring in the California Current, Sardinops sagax, Engraulis mordax and Trachurus symmetricus. Fishery Bulletin 74: 517-530.

Arula T, J Kotta, A Lankov, M Simm \& S Põlme. 2012. Diet composition and feeding activity of larval spring-spawning herring: importance of environmental variability. Journal of Sea Research 68: 33-40.

Boehlert GW \& JB Morgan. 1985. Turbidity enhances feeding abilities of larval Pacific herring, Clupea harengus pallasi. Hydrobiologia 123: 161-170.

Buskey EJ, C Coulter \& S Strom. 1993. Locomotory patterns of microzooplankton: potential effects on food selectivity of larval fish. Bulletin of Marine Science 53: 29-43.

Bustos CA, MF Landaeta \& F Balbontín. 2008. Spawning and early nursery areas of anchoveta Engraulis ringens Jenyns, 1842 in fjords of southern Chile. Revista de Biología Marina y Oceanografía 43: 381-389.

Cass-Calay SL. 2003. The feeding ecology of larval Pacific hake (Merluccius productus) in the California Current region: an updated approach using a combined OPC/MOCNESS to estimate prey biovolume. Fisheries Oceanography 12 : 34-48.

Castro LR, G Claramunt, MC Krautz, A Llanos-Rivera \& P Moreno. 2009. Egg trait variation in anchoveta Engraulis ringens: a maternal response to changing environmental conditions in contrasting spawning habitats. Marine Ecology Progress Series 381: 237-248.

Catalán IA, A Folkvord, I Palomera, G Quílez-Badía, F Kallianoti, A Tselepides \& A Kallianotis. 2010. Growth and feeding patterns of the European anchovy (Engraulis encrasicolus) early life stages in the Aegean Sea (NE Mediterranean). Estuarine, Coastal and Shelf Science 86: 299-312.

Chesson J. 1978. Measuring preference in selective predation. Ecology 59: 211-215.

Claramunt G, LR Castro, LA Cubillos, H-J Hirche, G Pérez \& M Braun. 2012. Inter-annual reproductive trait variation and spawning habitat preferences of Engraulis ringens off northern Chile. Revista de Biología Marina y Oceanografía 47: 227-243.

Conway DVP, SH Coombs \& C Smith. 1998. Feeding of anchovy Engraulis encrasicolus larvae in the northwestern Adriatic Sea in response to changing hydrobiological conditions. Marine Ecology Progress Series 175: 35-49.

Cortés E. 1997. A critical review of methods of studying fish feeding based on analysis of stomach contents: application to elasmobranch fishes. Canadian Journal of Fisheries and Aquatic Science 54: 726-738.

De Ciechomski JD. 1967. Investigations of food and feeding habits of larvae and juveniles of the Argentine anchovy Engraulis anchoita. CalCOFI Reports 11: 72-81.
González HE, MJ Calderón, L Castro, A Clement, LA Cuevas, G Daneri, JL Iriarte, L Lizárraga, R Martínez, E Menschel, N Silva, C Carrasco, C Valenzuela, CA Vargas \& C Molinet. 2010. Primary production and plankton dynamics in the Reloncaví Fjord and the Interior Sea of Chiloé, Northern Patagonia, Chile. Marine Ecology Progress Series 402: 13-30.

Govoni JJ, PB Ortner, R Al-Yamani \& LC Hill. 1986. Selective feeding of spot, Leiostomus xanthurus, and Atlantic croaker, Micropogonias undulatus, larvae in the northern Gulf of Mexico. Marine Ecology Progress Series 28: 175-183.

Gutiérrez M, R Castillo, M Segura, S Peraltillo \& M Flores. 2012. Trends in spatio-temporal distribution of Peruvian anchovy and other small pelagic fish biomass from 1966-2009. Latin American Journal of Aquatic Research 40: 633-648.

Hernández EH \& LR Castro. 2000. Larval growth of the anchoveta Engraulis ringens during the winter spawning season off central Chile. Fishery Bulletin 98: 704-710.

Herrera G \& F Balbontín. 1983. Rate of gut evacuation and feeding incidence in larvae of Sardinops sagax musica (Pisces, Clupeiformes). Revista de Biología Marina 19: 113132.

Hinrichsen H-H, JO Schmidt, C Petereit \& C Möllmann. 2005. Survival probability of Baltic larval cod in relation to spatial overlap patterns with their prey obtained from drift model studies. ICES Journal of Marine Sciences 62: 878885 .

Iriarte JL, HE González, KK Liu, C Rivas \& C Valenzuela. 2007. Spatial and temporal variability of chlorophyll and primary productivity in surface waters of southern Chile $\left(41.5-43^{\circ} \mathrm{S}\right)$. Estuarine Coastal and Shelf Science 74: 471480 .

Kato Y, T Takebe S Masuma, T Kitagawa \& S Kimura. 2008. Turbulence effect on survival and feeding of Pacific bluefin tuna Thunnus orientalis larvae, on the basis of a rearing experiment. Fisheries Science 74: 48-53.

Landaeta MF, N Suárez-Donoso, CA Bustos \& F Balbontín. 2011. Feeding habits of larval Maurolicus parvipinnis (Pisces: Sternoptychidae) in Patagonian fjords. Journal of Plankton Research 33: 1813-1824.

Landaeta MF, RA Martínez, CA Bustos \& LR Castro. 2013. Distribution of microplankton and fish larvae related to sharp clines in a Patagonian fjord. Revista de Biología Marina y Oceanografía 48(2): 401-407.

Lechowicz MJ. 1982. The sampling characteristics of electivity indices. Oecologia 52: 22-30.

Letelier J, L Soto-Mardones, S Salinas, P Osuna, D López, HH Sepúlveda, E Pinilla \& C Rodrigo. 2011. Variability of wind, waves and currents in the northern region of the Chilean Patagonian fjords. Revista de Biología Marina y Oceanografía 46: 363-377. 
Llanos-Rivera A \& LR Castro. 2004. Latitudinal and seasonal egg-size variation of the anchoveta (Engraulis ringens) off the Chilean coast. Fishery Bulletin 102: 207-212.

Llanos-Rivera A \& LR Castro. 2006. Inter-population differences in temperature effects on Engraulis ringens yolksac larvae. Marine Ecology Progress Series 312: 245-253.

Llanos A, G Herrera \& P Bernal. 1996. Análisis del tamaño de las presas en la dieta de las larvas de cuatro clupeiformes en un área costera de Chile central. Scientia Marina 60: 435-442.

Llanos-Rivera A, G Herrera \& P Bernal. 2004. Food size selectivity and diet overlap in larvae of Clupeiform species from central Chile. Cahiers de Biologie Marine 45: 1-8.

Mahjoub M-S, R Kumar, S Souissi, FG Schmitt \& J-S Hwang. 2012. Turbulence effecs on the feeding dynamics in European sea bass (Dicertranchus labrax) larvae. Journal of Experimental Marine Biology and Ecology 416-417: 61-67.

McManus MA \& CB Woodson. 2012. Plankton distribution and ocean dispersal. The Journal of Experimental Biology 215: 1008-1016.

Morote E, MP Olivar, F Villate \& I Uriarte. 2010. A comparison of anchovy (Engraulis encrasicolus) and sardine (Sardina pilchardus) larvae feeding in the Northwest Mediterranean: influence of prey availability and ontogeny. ICES Journal of Marine Science 67: 897-908.

Morote E, MP Olivar, A Bozzano, F Villate \& I Uriarte. 2011. Feeding selectivity in larvae of the European hake (Merluccius merluccius) in relation to ontogeny and visual capabilities. Marine Biology 158: 1349-1361.

O'Keefe TC, MC Brewer \& SI Dodson. 1998. Swimming behaviour of Daphnia: its role in determining predation risk. Journal of Plankton Research 20: 973-984.

Pepin P \& RW Penney. 1997. Patterns of prey size and taxonomic composition in larval fish: are there general size dependent models? Journal of Fish Biology 51(Suppl. A): 84-100.

Peterson WT \& SJ Ausubel. 1984. Diets and selective feeding by larvae of Atlantic mackerel Scomber scombrus on zooplankton. Marine Ecology Progress Series 17: 65-75.
Reiss CS, A Anis, CT Taggart, JF Dower \& B Ruddick. 2002. Relationships among vertically structured in situ measures of turbulence, larval fish abundance and feeding success and copepods on Western Bank, Scotian Shelf. Fisheries Oceanography 11: 156-174.

Sassa C \& K Kawaguchi. 2004. Larval feeding habits of Diaphus garmani and Myctophum asperum (Pisces: Myctophidae) in the transition region of the western North Pacific. Marine Ecology Progress Series 278: 279-290.

Sato NE, D Hernández \& MD Viñas. 2011. Feeding habits of Engraulis anchoita (Hubbs \& Marini, 1935) larvae in coastal waters off Buenos Aires Province, Argentina. Latin American Journal of Aquatic Research 39: 16-24.

Schmitt PD. 1986. Prey size selectivity and feeding rate of larvae of the northern anchovy, Engraulis mordax Girard. CalCOFI Reports 27: 153-161.

Sun J \& D Liu. 2003. Geometric models for calculating cell biovolume and surface area for phytoplankton. Journal of Plankton Research 25: 1331-1346.

Tudela S, I Palomera \& G Quílez. 2002. Feeding of anchovy Engraulis encrasicolus larvae in the north-west Mediterranean. Journal of Marine Biological Association of the United Kingdom 82: 349-350.

Valle-Levinson A, N Sarkar, R Sanay, D Soto \& J León. 2007. Spatial structure of hydrography and flow in a Chilean fjord, Estuario Reloncaví. Estuaries and Coasts 30: 113126.

Vasconcellos MC, KF Freire \& JP Castello. 1998. Distribution patterns and feeding success of anchovy, Engraulis anchoita, larvae off southern Brazil. Scientia Marina 62: 385-392.

Woodson CB \& MA McManus. 2007. Foraging behaviour can influence dispersal of marine organisms. Limnology and Oceanography 52: 2701-2709.

Yañez-Rubio A, A Llanos-Rivera, LR Castro, G Claramunt \& L Herrera. 2011. Variations in type, width, volume and carbon content of anchoveta Engraulis ringens food items during the early life stages. Journal of Marine Biological Association of United Kingdom 91: 1207-1213. 